\title{
The seafood market in Portugal: driving forces and consequences
}

\author{
Cheila Almeida ${ }^{1,2,3^{*}}$, Vanja Karadzic ${ }^{2}$, Sofia Vaz ${ }^{2}$ \\ ${ }^{1}$ MARE - Marine and Environmental Sciences Centre, Faculdade de Ciências, Universidade de Lisboa, Lisbon, Portugal \\ ${ }^{2}$ CENSE - Centre for Environmental and Sustainability Research, Faculdade de Ciências e Tecnologia, Universidade Nova de \\ Lisboa, Lisbon, Portugal \\ ${ }^{3}$ Sik - The Swedish Institute for Food and Biotechnology, Gothenburg, Sweden \\ * Corresponding author. Tel.: +351 914623888; E-mail address: cheilapalmeida@yahoo.com
}

\begin{abstract}
Portugal has the third highest seafood consumption per capita in the world and current patterns of seafood consumption are linked to how seafood products were embodied in the Portuguese society. The objective of this research is to understand Portuguese seafood consumption's main drivers and its consequences. For that official statistics were analysed and a literature review on seafood consumption was undertaken. Portuguese seafood consumption is characterized by a wide diversity of species and preparing modes, when compared to other countries in Europe. Cod (salted and dried), doesn't exist in Portuguese waters but due to several factors, such as politics, religion and tradition, became the main species in Portuguese seafood consumption, representing around $38 \%$ of the national seafood demand. Five drivers are suggested to explain why Portuguese eat so much seafood: geography, marine resources, fisheries, social forces and politics; and consequences for the environment, economy and health are discussed. Hence while most dietary recommendations advise an increase in fish consumption is not applicable to Portugal and a more sustainable seafood consumption for the future is advocated.
\end{abstract}

\section{Keywords}

Seafood consumption; fish; cod; habits; drivers; Portugal 


\section{Introduction}

Human diet has undergone significant changes in recent decades contributing significantly to global environmental impacts [1]. As an example, livestock production is responsible for $10 \%$ of European greenhouse gas (GHG) emissions and several other consequences for the environment, such as habitat destruction, pollution and biodiversity loss [2]. The mitigation of some of these impacts should be implemented, not only by changing production systems, but also consumer preferences related to their diets [3].

Marine resources have been traded more than any other food commodity and represent one of the most nutritious and healthy foods, with high quality animal protein and a low fat content [4, 5]. Fish is widely reported as an important source of essential amino acids, long-chain polyunsaturated fatty acids, vitamins, minerals, and trace elements [6]. It contributes with at least $15 \%$ of worldwide animal protein consumed and up to $50 \%$ in some coastal states $[7,8]$.

The feasibility of increasing fish consumption, as a dietary recommendation, needs to be balanced with the sustainability of marine stocks [9]. In fact, around two thirds of the assessed fish stocks worldwide are overfished and lower exploitation rates are needed to reverse the collapse of vulnerable species [10]. One of the reasons that make marine systems' vulnerable is the supply of the worlds' major seafood markets as EU, Japan and USA, which are largely dependent on seafood sources well beyond their domestic waters [11]. The worldwide supply of seafood from fisheries peaked in 1986 and farmed seafood has been increasing since 1970 at an annual rate of 7\% [7]. It is fundamental to understand the reasons behind this global demand, as it represents a main driver of fishing pressure [12].

Dietary patterns are related not only to economic dynamics but also to cultural factors [13]. The main fish species used in meals have changed through time and the interest for species in higher trophic levels and vulnerable species have been increasing [14]. From historical, cultural, social, but especially ecological perspectives, it is important to understand how such behaviour is influenced by several factors and identify the main drivers of change [15]. 
Portugal is the country with the highest seafood consumption in Europe and one of the largest in the world [16], but knowledge concerning which species are most consumed, its trends and forcing factors are extremely scarce. This study, addresses two main questions: i) what seafood do Portuguese eat? and ii) why do Portuguese eat so much seafood? To answer these questions the species and quantities of Portuguese seafood landings and consumption were investigated; and environmental, social, economic, and even the political factors that may be recognised as the main drivers of Portuguese diet habits were analysed.

\section{Methodology}

Diets are shaped by different drivers such as production, post-harvest chain, traditions, geography, demography, globalization, religion and culture [4]. Altogether they contribute to the dynamics of seafood consumption. In order to understand the different drivers and consequences of seafood consumption, both quantitative and qualitative data were combined. Looking at different indicators in an integrated way allow a comprehensive analysis of the seafood system. For the purpose of this paper, seafood includes all major captured and farmed edible aquatic food products entering in the human food chain, including fish, crustaceans, and molluscs. The data was obtained from two different sources: apparent consumption (Food Balance Sheet (FBS) from Food and Agriculture Organization (FAO) statistics (FAOSTAT) [17]) and market flows (namely Portuguese Food Balance database, household budget and population surveys).

The fundamental information on Portuguese fisheries and aquaculture was obtained from Portuguese National Institute of Statistics (INE), which produces annual reports on Fishery Statistics (Estatísticas da Pesca) since 1969 (INE) [18]. Earlier data exists, beginning in 1938, but has a weak resolution since most species are grouped in commercial categories, with only few species-level data (e.g. sardine). Publications such as the Portuguese Food Balance (Balança Alimentar Portuguesa) have been published in four volumes gathering different time periods (1963 - 73; 1963 - 1975; 1980 - 
1992; 1990 - 1997; 2003 - 2008) [19-23]. For previous periods information was collected from two publications with general information on Portuguese diets from the beginning of the $20^{\text {th }}$ century: Abecasis [24] and Correia [25]. Portuguese national health surveys were conducted during 1987, 1995/1996, 1998/1999, and 2005/2006 [26, 27]. The sampling frame included people living in individual housing and information on individual food intake. For the relative seafood consumption by species Rodgers et al. [28] was used, a report about fisheries products for the European Parliament's Committee, and Cardoso et al. [29], a research study based on internet surveys.

When interpreting consumption data, different data sources have different methodological limitations that need to be considered. Data from both FBS and individual surveys are not directly comparable but can complement each other [30]. There are limitations related to the statistical sources and it is difficult to correctly assess values of per capita consumption by type of product [31]. The FBS reflects national per capita supply at retail level for human consumption and represents the food produced and imported into countries minus the food exported, food that was used to feed animals or otherwise not available for human consumption, divided by the population size [16]. The FBS can show long-term trends but it does not represent the amount of food that is actually consumed because it tends to overestimate food consumption when compared with individual surveys [4]. On the other hand individual surveys are biased, since it is difficult to cover population homogenously and people participating in the study are influenced by different methodologies (e.g. internet surveys, face-to-face, phone).

To complement the quantitative data, it descriptive information was used to understand the reasons behind seafood demand. Furthermore, relevant historical events were analysed that influenced Portuguese society and its diet traditions. A detailed literature review was carried out concerning seafood in Portugal in order to build a narrative that describes the known demand [24, 25, 29, 32 37]. Time periods were then defined with different seafood consumption patterns related to historical events. Based on the framework from Kearney [4], the main drivers that are considered 
important to shape current seafood consumption in Portugal were analysed and their consequences were evaluated.

\section{Results}

\subsection{Seafood market in Portugal}

Portuguese seafood production from fisheries in recent years represents around 160 thousand tonnes and 270 million Euros, per year [17]. Portuguese fishery landings are composed of almost 40 different categories from different taxonomic groups, such as fish, cephalopods, crustaceans and molluscs, comprising ca. 200 different species. Marine pelagic fish landings in Portugal are dominated by sardine, which represents more than $40 \%$ of fish landings by weight, followed by chub mackerel, tuna and horse mackerel (Fig. 1). It is interesting to note that other seafood products such as molluscs have significant production since 1986 and octopus is nowadays the most important Portuguese seafood product in value. Aquaculture production, represented mainly by species such as clam, gilthead seabream, sea bass and turbot, corresponds only to $5 \%$ of the seafood produced in Portugal [18].

Figure 1 about here

Sardine has been the most important species in Portuguese fisheries for a long time. Sardine landings reached the highest value in 1964, with a second peak in landings registered in 1984. From 1984 until recent years sardine's landings values have been relatively stable (Fig. 1). In the beginning of the $20^{\text {th }}$ century, the canned fish industry had a strong development associated with the sardine purse seining fishery together with the Second World War that increased canned products consumption [38]. After 1969, a period of low sardine production occurred, probably related to overfishing. Nevertheless, the sardine stock recovered and, in 1975, the fleet with around 200 vessels targeting 
sardine was responsible for $34 \%$ of the total landings [20]. Sardine still continues to be the most important product in quantity. It is also the only fish that is under the Marine Stewardship Council certification program since 2010 [39].

The other important species in Portuguese seafood consumption is cod (Fig. 1). The importance of salt and dried cod in Portugal dates back to the $15^{\text {th }}$ century, according to the first records of Portuguese fishing cod in the Northwest Atlantic [33]. It was the Basque fishermen that disseminated the curing technique of salting fish before drying to prepare bacalhau [40]. In the second part of the 19th century the Portuguese cod fishery increased due to a tax reduction on fish. However, national production did not cover more than $10 \%$ of seafood consumption at that time [33]. In 1920, the imports of salted and dried cod from Portugal were the second highest (17\%) after Spain [32].

The establishment of Exclusive Economic Zones (EEZ) seriously restricted the Portuguese cod fishery [35]. Cod production declined from the 1970 s onwards, due to restrictions to fishing in international waters. Despite efforts of the fleet conversion, a predominance of smaller and less valuable codfish in Portuguese landings was evident [41]. In 1986, with the entry of Portugal to the European Economic Community (EEC), the fishery sector changed completely due to the replacement of bilateral agreements (e.g. with Canada) to supra-national management by the European Commission (EC), and structural changes to the fleet and catches under the Common Fisheries Policy (CFP) [36]. In the 1990s, problems related to overfishing of stocks reinforced the cod production decrease. As populations declined, fishing mortality and discarding of juveniles increased to a point of commercial extinction, and in 1993, after the collapse of Eastern Atlantic cod stocks of the Grand Banks, a moratorium was declared on cod fishing [42]. However, cod food traditions and the associated processing industry remained and the Atlantic cod is still the major imported species, representing more than $60 \%$ of the imports of seafood [34]. The Portuguese cod industry continues to produce salted and dried cod, but with fish imported due to the low level cod production and traditionally low labour costs $[28,43]$. Nowadays, most of the cod processed in Portugal comes from Norway, Iceland and Russia, frozen or as salty green cod [36]. Portugal is by far the largest market for Norwegian 
dried salted cod; the imports reached 41 thousand tonnes, representing $60 \%$ of Norwegian exports of this product [43].

Currently, Portuguese seafood production overall is following a downward trend and the national production only fulfills part of demand. Imports represent around two thirds of the Portuguese seafood supply and are four times higher than exports (Fig. 2). Since 1967 Portugal has been increasingly dependent of an external supply of seafood and the deficit of the Portuguese seafood commercial balance has been increasing. The upward trend of seafood imports grew from $16 \%$, between 1987 and 1991, to 38\%, between 1990 and 1997 [21, 22]. In 2010, the imports represented $52 \%$ of the seafood supply and the negative balance was around 226 thousand tonnes and 666 million Euros.

Figure 2 about here

\subsection{Seafood demand in Portugal}

The imbalance in the seafood market is strongly influenced by Portuguese seafood demand. Presently the national production supplies a per capita consumption of only $23 \mathrm{~kg}_{\mathrm{year}}{ }^{-1}$, when the current consumption is around $62 \mathrm{~kg}$ year ${ }^{-1}$ [16]. Compared to the world average, which rises every year and grew from $11 \mathrm{~kg}$ per capita, in 1970, to $19 \mathrm{~kg}$ per capita, in 2010 [5], seafood consumption in Portugal is still about twice as high (Table 1).

Table 1 about here

Dietary patterns have changed considerably in Portugal, shifting from a traditional south European diet with more carbohydrate-rich staples (cereals and roots), in a more protein-rich diet with more animal products (meat and dairy) [26]. In the 1970s the contribution of protein in diets was mainly coming from cereals and rice (33\%), and only $19 \%$ and $16 \%$ from meat and seafood respectively, but 
in the 1990 s meat provided the highest contribution, with $29 \%$, and seafood with $13 \%$ [21, 22]. Data from National Health Surveys show a decrease in fish consumption in the recent years in Portugal although total seafood consumption increased due to other species rather than fish (Table 2). There was also an increase in meat consumption, which along with seafood consumption is also very high. Compared to the worldwide average meat consumption, Portuguese meat consumption is $93 \mathrm{~kg}$ per capita against $42 \mathrm{~kg}$ per capita (Table 1), and even though seafood consumption has always being quite high in Portugal, it is not the main protein source. From the total daily animal protein intake in Portugal, $67 \mathrm{~g}$ per capita, only $16 \mathrm{~g}$ comes from seafood, representing $23 \%$ [31].

Table 2 about here

Cod is the most consumed fish representing around $38 \%$ of the seafood consumption in Portugal (Figure 3). After cod, the second most consumed specie is tuna, but with a consumption value almost five times lower (7\%). Canned tuna is a staple product in Portugal, consumed by most of the people from one to four times a month [29]. It has become increasingly convenient according to food habits of modern lifestyles and an increased demand for pre-packed and easy prepared food [45]. Hake is third most consumed species (with 6\%). Its importance can be related to the fact that frozen hake products became very popular in the beginning of the $20^{\text {th }}$ century. In 1967 , hake consumption was already higher than production [41]. Its price as a frozen product was lower than fresh fish due to fisheries expansion to African countries and improvements in processing technology on board fishing vessels [44].

Figure 3 about here

Fresh seafood is predominant in Portuguese food consumption, followed by salted and dried fish almost exclusively of cod [31]. In Cardoso et al. [29] survey of Portuguese seafood preferences in the 
"like much" category, fresh fish represents $83 \%$, salted/dried $17 \%$ and frozen, smoked and canned have all an equal value of $11 \%$ of "like much" preferences. The high preference of fresh seafood requires a constant supply and means that consumers are willing to pay higher prices for a better quality fish product [28]. Moreover, in line with Portuguese culinary conventions, fresh fish is mostly served whole with bones and grilled [29], which is not common in other countries. In northern Europe for example, there is an aversion of consumers towards the "whole" fish, and fillets are the common way to prepare it [45], as well as fish that have undergone a considerable degree of processing [28]. In fact, tradition and cultural influences on the acceptability of different species can be one of the reasons for a higher number of species consumed in southern Europe [46]. This might explain why Portuguese seafood demand is remarkably diversified, and several species, with less than $2 \%$ of the Portuguese seafood consumption, altogether represent $36 \%$ of seafood consumption (Fig. 3).

In the beginning of the $20^{\text {th }}$ century the Portuguese diet was monotonous and mainly composed by bacalhau, the main animal protein source together with bread, vegetables, and olive oil; and on the other hand, meat, milk or sardines were scarce [25]. In some socio-economic classes or regions there was a lack of animal protein since meat was expensive and seafood from Portuguese fishery had not a sufficient supply [19]. However, it was difficult to increase Portuguese seafood consumption due to the lack of a network and infrastructures to maintain and commercialize fish [41]. In the 1930s and during the Second World War, food production decreased in Europe and it became more expensive, reaching almost $60 \%$ of the household budget [19]. To solve part of that problem, the importance of cod increased in the 1940s with the "Cod campaign" (1934 - 67), implemented by the Portuguese Government (period known as Estado Novo (1933-1974)) based on strong protection of Portuguese cod fishery [35]. This cod campaign aimed at improving the cod trade balance through the reduction of imports and protection of the associated cod industries, namely the cod drying industry [36]. The control of cod prices on the domestic market encouraged consumption and as a result cod intake 
tripled during this period and the fleet went from 51 vessels, mostly with hook and line gears, to 65 vessels, of which 32 were trawlers [33].

Despite the importance of cod in the Portuguese seafood consumption, it is difficult to estimate accurate values of cod flows since cod can be imported from different sources and in different products (e.g. frozen, salted-dried) and the figures depend substantially on how cod is included in the statistics. As suggested by Dias et al. [33], statistical data from the cod supply often lags between capture and landings and it can be anomalous in some years. The difficulties of comparing statistical data can result in different seafood trends, as for example Willemsen [47] identified that between 1992 and 1994 the Portuguese seafood consumption per capita in national statistics was $37.4 \mathrm{~kg}$ year $^{-1}$, however, if cod was converted to fresh fish, which is the normal procedure in FAO statistics, the Portuguese seafood consumption would be $61.6 \mathrm{~kg} \mathrm{year}^{-1}$.

\section{Discussion}

4.1 Main periods of different seafood consumption patterns

The analysis of trends in Portuguese seafood demand allows establishing the three main periods shown in Figure 4. Each period is related to specific drivers and characterized by a prominent consumption pattern:

- The first period is between 1961 and 1972 and was named as "Corporate political fish" because of the establishment of the "Cod campaign". This political driven campaign increased seafood consumption in Portugal to its maximum level. In that sense, it was a successful strategy with further important consequences for the Portuguese food traditions.

- The second period, between 1972 and 1985, was characterized by a political and economic instability and forced consumption to decrease, so this period was named as "Fisheries crisis". The Portuguese revolution of 1974, which ended the Estado Novo, was important for 
this period. Nevertheless Portuguese seafood consumption in 1975 was the highest in Europe. At that time increasing seafood consumption was no longer a priority [41].

- The last period, from 1986 until 2009, is the "Adaptive fisheries to EU", since there were several European restrictions to fisheries but nevertheless the consumption rose and it was more diversified than ever. Between 1990 and 1997 a new upward trend in seafood consumption was observed. Despite a decrease in fish, it was compensated by an increase of $4 \%$ in crustaceans and molluscs, and of 15\% in salted dried cod [22]. During 2003 and 2008 seafood consumption continued to increase, around $15 \%$, but cod consumption decreased $20 \%$, from 5.6 to $3.6 \mathrm{~kg}$ per capita and per year [23].

These three periods allow to characterizing the patterns of Portuguese seafood consumption. To better understand it, a framework (Fig. 5) that explains and explores both the drivers and the consequences was followed.

Figure 4 about here

\subsection{Drivers}

Based on the data, literature review and on an analysis on the Portuguese seafood demand overview, five main drivers that explain why Portuguese eat so much seafood are suggested: geography, resources, fisheries, social forces and politics. Each of these drivers has a role on how Portuguese eat seafood and their integrated analysis allows us to understand the importance of seafood in Portuguese food habits. In order to justify the selection of these drivers, a brief characterization follows: 


\section{Geography}

Portugal is a country with a large coastal area $(1187 \mathrm{~km}$, including its mainland, Madeira and Azores archipelagos), a vast EEZ (1.7 million $\mathrm{km}^{2}$ ) and $76 \%$ of the Portuguese population lives in coastal areas [48]. Portuguese consumption of food has always been strongly based on marine resources. The only countries with a higher seafood consumption compared to Portugal are Iceland and Japan, both island territories [16].

\section{Fisheries heritage}

Fishing is part of the Portuguese social and cultural heritage and a way of subsistence, in particular for coastal communities that depend almost exclusively on fisheries and related activities as processing industries [49]. In 1960, the contribution of fisheries to the gross domestic product of Portugal was one of the highest in Europe, only surpassed by Norway [41]. Nevertheless, since the 1960s, the fleet has been reduced with a noticeable decreasing trend in landings over the last two decades [49] and it is currently the fourth in terms of number of vessels and level of employment in the European Union [50].

\section{Resources}

The country is in a transition zone between warm- and cold-temperate biogeographical regions which explains, in part, its high diversity of marine species. Portuguese fisheries landings includes almost 40 different species categories (more than 200 species) and the diversity of seafood products compared to other European countries reflects the variety of marine habitats in Portuguese coastal waters [28]. The high production of small pelagic fish (e.g. sardine) is mainly related to a coastal upwelling system that generates the basis of marine food webs [49]. 
Social

The Portuguese culinary traditions are linked to habits of eating small pelagic fish, whole fish prepared with bones and different type of seafood (e.g. octopus, cuttlefish and squids) [29]. On the other hand, since Portugal is a Catholic country, there were religious influences. Fish is linked with Christianity with several associations regarding fish or fishery themes in the Bible [37]. It was believed that abstaining from animal flesh in fasting days contributed to discipline and enhanced virtues, and since the medieval era that meat was forbidden on Fridays and vigils for major feasts, as Eastern and Christmas [36]. Fish, mostly bacalhau, became preponderant on those days because drying and salting was used to store fish and the high capacity of conservation of bacalhau made it a vital product for long-distance trade $[36,51]$. It was often used in the period of navigation and worldwide discoveries, in the $15^{\text {th }}$ and $16^{\text {th }}$ centuries [36]. From then on this product has been present in the Portuguese diet but the importance in Portuguese cooking began in the $19^{\text {th }}$ century [32]. Cod was therefore rooted in the Portuguese culinary culture persisting up to present days in food habits and it still is the main dish over Christmas in most Portuguese households.

\section{Politics}

Food production worldwide was heavily affected by Second World War and as a result governments engaged in the implementation of food rationing systems that regulated both food supply and demand [52]. The political regime Estado Novo (1933 - 1974) promoted the cod fishery and its importance in Portuguese culinary traditions [37]. The government pretended to be less dependent on imports and to become the main intermediate with other countries and processing industries, in order to guarantee food supply at a stable price regime and fish affordable to everyone [35]. To overcome the limited cod supply, in 1960, the Estado Novo government defined regulations for fresh fish market establishing settings and profit margins to control the prices and fill up the lack of animal protein with fish landed in Portugal. 
These five drivers have to be understood in a complementary way, as they reinforce each other. They help us to understand the complexity of the seafood production and consumption system in Portugal.

Figure 5 about here

\subsection{Consequences}

Even if Portugal has one of the highest seafood consumption per capita, in absolute values, compared to other countries, the country has a relatively small population (ca. 10 million inhabitants). However, it is an interesting case study that has consequences for the environment, economy and health.

\section{Economy}

As already explained, Portuguese production does not fulfil the demand but the industry continues to make seafood available from all over the world. One of the main economic consequences of Portuguese high consumption comes from the fact that almost two thirds of seafood is imported. This is important both for the Portuguese economy and for the global demand of seafood in other parts of the world. Another economic consequence concerns the seafood value chain. The high and diversified consumption are key determinants of the quantity, species and product that people consume by affecting the cost, availability, and desirability of different fish [9]. This value chain affects economic flows from several stakeholders namely importers, fishermen, industry, retailers and markets. In other countries the popularity of healthy diets and publicity campaigns have been responsible for growing preference for fish in European countries. As a consequence fish markets are recording increase in prices due to the contraction in supply and increase in demand [28].

Environment 
There are consequences for the marine environment that can be claimed based on the knowledge of fishing impacts on the ecosystem (e.g. lack of management, biodiversity loss, by-catch) resulting in a mosaic of stable, declining, collapsed, and rebuilding fish stocks and ecosystems [10]. A significant fraction of stocks will remain depleted, especially in poorer regions, unless a global perspective on rebuilding marine resources emerges to reduce exploitation rates [53]. The fact that EU seafood market is strongly dependent on seafood supplies well beyond its domestic waters (Portugal in particular), should imply a more responsible use of resources in order to avoid depleting local fish stocks in other parts of the world [11]. Furthermore, there are $\mathrm{CO}_{2}$ emissions related to the logistics chain that need to be taken into account as environmental impacts [54]. If the entire world population ate as much seafood as Portuguese, even higher GHG emissions would come from diets [2]. Lower consumption of seafood products in high-consuming countries could yield significant environmental associated benefits for global food security and marine biodiversity.

Health

Besides benefiting the environment and the economy, reducing seafood in Portuguese diets could also improve public health by preventing the risk of toxic substances intake. Consumers perceive fish as healthy food but there are also undesirable consequences from overconsumption of seafood. Due to the risk of heavy metals, such as mercury, intake from tuna, which is a highly consumed fish in Portugal, responsible authorities in some countries give advice on a maximum intake [6]. In particular, people who eat more than three servings of fish weekly, or more than three to four servings per month of large predatory fish, should consider lowering their intake or measuring their mercury level to determine if they are at risk [55]. The European Food Safety Authority recommends that women of childbearing age, pregnant and breastfeeding, as well as young children, select fish from a wide range of species, without giving undue preference to large predatory fish, such as swordfish and tuna, and says that each country needs to consider its own pattern of fish consumption and carefully assess the risk of exceeding the tolerable intake of methylmercury while 
obtaining the health benefits from consumption of seafood [56]. There is no national policy regarding these issues in Portugal but, since seafood consumption is higher than in most of other European countries, a public health message of balance in diet would be desirable by highlighting the risk of consuming certain fish species excessively [57]. Furthermore, it is recommended that countries develop national lists of fish that can be eaten freely or moderately and fish that should be avoided, and these lists should consider several perspectives, integrating health, ecological and economic information of different seafood [9].

Increasing seafood consumption, contrary to most dietary guidelines elsewhere, is not applicable to Portugal. Diets have enough protein and it would exert even more pressure on fisheries already stressed by over-fishing and contribute to the protein scarcity in other parts of the world. Moreover it is important to note that if fish is substituted by other animal products, such as meat or dairy, that would represent an even higher cost for the environment. Therefore dietary guidelines for Portuguese should integrate environmental considerations into policy development. As mentioned before, very high seafood consumption has also health implications that cannot be avoided among the Portuguese population regarding for example to risks of high mercury intake.

The demand seems to be strongly affected by practices since Portuguese never got used to eat fresh cod and continue faithful to bacalhau [33]. The preservation process of cod promote important sensory changes that remain during cooking [51] however, not only traditions influence the demand, since Portuguese dietary patterns have changed considerably to a more protein-rich diet with more animal products. If the consumption pattern is maintained as it has been recently, consumers should have guidance on the consequences of their choices and the relative impacts of different species. In order to improve knowledge about seafood it would be desirable to better connect the consumers with seafood producers and products, allowing for example to support more local fishing communities or small-scale fisheries [58]. 


\section{Conclusions}

Portugal has one of the highest levels of seafood consumption in the world and cod is the most important fish in the Portuguese diet. It was concluded that drivers such as geography, marine living resources, fishery heritage, politics and social forces, such as religion and social habits, influenced in an integrated way seafood consumption patterns. The former preference for salt and dried cod remains and culinary traditions are also linked to a high diversity of resources apart from fish (e.g. cephalopods) and to the habit of eating small pelagic fish as whole fish prepared with bones. The high consumption has consequences for the environment, related to overfishing of marine resources; economy, due to implications regarding imported products and even though the use of seafood in human nutrition, since an overconsumption can also bring health problems.

Sustainable consumption is often associated with environmental consciousness, but social forces and governance are also responsible for shaping individual habits, as suggested here. To change seafood consumption patterns rooted for many years in Portuguese culture would be difficult but to recommend a reduction of seafood intake or diversify the species as much as possible could be a first approach towards a more sustainable consumption. Nevertheless it illustrates the difficulties that consumers have when choosing a balanced and sustainable diet.

\section{Acknowledgments}

Cheila Almeida wishes to thank FCT for the financial support (SFRH / BD / 60187 / 2009). The authors would like to thank António Silva at the Universidade de Coimbra for his useful comments on the manuscript.

\section{References}

[1] Infante Amate J, González de Molina M. Sustainable de-growth in agriculture and food: an agroecological perspective on Spain's agri-food system (year 2000). J Clean Prod 2013; 38: 27-35. 
[2] Westhoek H, Rood T, Van den Berg M, Janse J, Nijdam D, Reudink M, Stehfest E. The protein puzzle. The Hague: PBL Netherlands Environmental Assessment Agency; 2011.

[3] Garnett T. Food sustainability: problems, perspectives and solutions. P Nutr Soc 2013; 72 (01): 2939.

[4] Kearney J. Food consumption trends and drivers. Philos T Roy Soc B 2010; 365 (1554): 2793-2807.

[5] Tacon A, Metian M. Fish matters: importance of aquatic foods in human nutrition and global food supply. Rev Fish Sci 2013; 21 (1): 22-38.

[6] Ström S, Helmfrid I, Glynn A, Berglund M. Nutritional and toxicological aspects of seafood consumption - An integrated exposure and risk assessment of methylmercury and polyunsaturated fatty acids. Environ Res 2011; 111 (2): 274-280.

[7] Food and Agriculture Organization (FAO). The state of world fisheries and aquaculture 2009 (SOFIA). FAO Fisheries and Aquaculture Department, Rome; 2010.

[8] Smith MD, Roheim CA, Crowder LB, Halpern BS, Turnipseed M, Anderson JL et al. Sustainability and global seafood. Science 2010; 327 (5967): 784-786.

[9] Oken E, Choi AL, Karagas MR, Mariën K, Rheinberger CM, Schoeny R, Sunderland E, Korrick S. Which fish should I eat? Perspectives influencing fish consumption choices. Environ Health Persp 2012; 120 (6): 790.

[10] Worm B, Hilborn R, Baum JK, Branch TA, Collie JS, Costello C, Zeller D. Rebuilding global fisheries. Science 2009; 325 (5940): 578-585.

[11] Swartz W, Sumaila UR, Watson R, Pauly D. Sourcing seafood for the three major markets: The EU, Japan and the USA. Mar Pol 2010; 34 (6): 1366-1373.

[12] Levin PS, Dufault A. Eating up the food web. Fish Fish. 2010; 11 (3): 307-312.

[13] York R, Gossard MH. Cross-national meat and fish consumption: exploring the effects of modernization and ecological context. Ecol Econ 2004; 48(3): 293-30.

[14] Apostolidis C, Stergiou K.I. Fish ingredients in online recipes do not promote the sustainable use of vulnerable taxa. Mar Ecol Progr Ser 2012; 465: 299-304. 
[15] Fabinyi M. Historical, cultural and social perspectives on luxury seafood consumption in China. Environ Conserv 2012; 39 (01): 83-92.

[16] Food and Agriculture Organization (FAO). Fishery and Aquaculture Statistics 2008. Statistics and Information Service of the Fisheries and Aquaculture Department, FAO Yearbook. FAO Fisheries and Aquaculture Department, Rome; 2010.

[17] FAOSTAT database www.http://faostat.fao.org [accessed 2011].

[18] Instituto Nacional de Estatística (INE). Estatísticas da Pesca. Lisbon [accessed 2011].

[19] Campos, J.S., 1977. Balanças Alimentares - A balança alimentar do continente Português, período 1963-73. INE, Lisbon.

[20] Instituto Nacional de Estatística (INE). Balança Alimentar Portuguesa - período 1963-75, INE, Lisbon; 1977.

[21] Instituto Nacional de Estatística (INE). Balança Alimentar Portuguesa - período 1980-92. INE, Lisbon; 1994.

[22] Instituto Nacional de Estatística (INE). Balança Alimentar Portuguesa - período 1990-97. INE, Lisbon; 1999.

[23] Instituto Nacional de Estatística (INE). Balança Alimentar Portuguesa - período 2003-08. INE, Lisbon; 2010.

[24] Abecasis HM. Alguns aspectos dos problemas alimentares, Centro de Estudos Demográficos, INE, Lisbon; 1952.

[25] Correia AM. A alimentação do povo português, Centro de Estudos Demográficos, INE, Lisbon; 1951.

[26] Marques-Vidal P, Ravasco P, Dias CM, Camilo ME. Trends of food intake in Portugal, 1987-1999: results from the National Health Surveys. Eur J Clin Nutr 2006; 60 (12): 1414-1422.

[27] Instituto Nacional de Estatística (INE), National Health Institute (INSA). Portuguese National Health Survey - 2005 / 2006. INE, Lisbon; 2009. ISSN 1646-4052. 
[28] Rodgers P, Dawson A, Espino DC, Dias JF, García del Hoyo JJ, Ordaz FG, Toribio RJ, Kapantagapis A, Lasch R, Le Grel L, Mendonça M, Pirazzoli C. Marketing and Price Formation of Fisheries and Aquaculture Products. European Parliament's Committee on Fisheries study; 2008.

[29] Cardoso C, Lourenço H, Costa S, Gonçalves S, Nunes ML. Survey into the seafood consumption preferences and patterns in the Portuguese population. Gender and regional variability. Appetite 2013; 64: 20-31.

[30] Rodrigues SSP, Lopes C, Naska A, Trichopoulou A, De Almeida MDV. Comparison of national food supply, household food availability and individual food consumption data in Portugal. J Public Health 2007; 15 (6): 447-455.

[31] Lopes R. MASMANAP country report: Portugal. Seafood market studies for the introduction of new aquaculture products. Cahiers Options Méditerranéennes 2002; 241-263.

[32] Moutinho MC. História da pesca do bacalhau: por uma antropologia do" fiel amigo", Editorial Estampa; 1985.

[33] Dias JF, Filipe JC, Guia F, Menezes R, Guerreiro V. A saga do fiel amigo: as indústrias portuguesas do bacalhau. Global Economics and Management 2001; 1: 1-11.

[34] Dias JF, Guillotreau P. Fish canning industries of France and Portugal: life histories, Economia Global e Gestão 2005; 10 (2): 61-79.

[35] Garrido A. Economia e Política das Pescas Portuguesas, ICS; 2006.

[36] Coelho M, Lopes R, Filipe JA, Ferreira MA. Cod and Tradition, Cultural Effects of Cod Fisheries in Portugal. Rocz Socjol Mor 2011; 20: 27-39.

[37] Sobral JM, Rodrigues P. O "fiel amigo": o bacalhau e a identidade portuguesa, Etnográfica 2013; 17 (3). DOI: 10.4000/etnografica.3252.

[38] Santos MPN, Seixas S, Aggio RBM, Hanazaki N, Costa M, Schiavetti A, Dias JA, Azeiteiro UM. A Pesca enquanto Atividade Humana: Pesca Artesanal e Sustentabilidade. Revista de Gestão Costeira Integrada, 2012; 12(4): 405-427. 
[39] Marine Stewardship Council (MSC). Portuguese sardine fishery MSC certificate reinstated, 2013 [accessed 2013].

[40] Kurlansky M. Cod. A biography of the fish that changed the world, Jonathan Cape, London; 1999.

[41] Varão AP, Garcia AM. Pesca Marítima - Situação e perspectivas de desenvolvimento, №8, Banco de Fomento Nacional de Estudos; 1975.

[42] Myers RA, Hutchings JA, Barrowman NJ. Why do fish stocks collapse? The example of cod in Atlantic Canada. Ecol Appl 1997; 7 (1): 91-106.

[43] Haagensen K. Trender i Salt/klippfisk markedet. Trusler og trender. Presentation at Marin Samhandlingsarena, 18.10.2011. Rica Parken, Ålesund; 2011.

[44] Piquero-Zarauz S., López E. El consumo de pescado en España. Siglos XVIII-XIX. Una primera aproximación. XI Congreso de Historia Agraria, Aguilar de Campoo; 2005.

[45] Papageorgiou PA. National Seafood Market Information and Analysis of Demand Factors, in: Paquotte, P., Mariojouls, C., Young, J. (Eds.), Seafood Market Studies for the Introduction of New Aquaculture Products, Mediterranean Agronomic Institute of Zaragoza (CIHEAM-IAMZ), Zaragoza; 2002.

[46] Welch AA, Lund E, Amiano P, Dorronsoro M, Brustad M, Kumle M. et al. Variability of fish consumption within the 10 European countries participating in the European Investigation into Cancer and Nutrition (EPIC) study. Public Health Nutr 2002; 5 (6b): 1273-1285. DOI: 10.1079/PHN2002404

[47] Willemsen F. Report on the seafood consumption data found in the European countries of the OT-SAFE project; 2003.

[48] Euroepean Comission (EC) 2008. EU Maritime policy. Facts and figures: Portugal. ISBN: 978-9279-09013-4 
[49] Leitão F, Baptista V, Zeller D, Erzini K. Reconstructed catches and trends for mainland Portugal fisheries between 1938 and 2009: implications for sustainability, domestic fish supply and imports. Fish Res 2014; 155: 33-50.

[50] Scientific, Technical and Economic Committee for Fisheries (STECF), 2013. The 2013 Annual Economic Report on the EU Fishing Fleet (STECF-13-15). Publications Office of the European Union, Joint Research Centre, Scientific and Technical Reports, Luxembourg.

[51] Oliveira H, Pedro S, Nunes ML, Costa R, Vaz-Pires P. Processing of Salted Cod (Gadus spp.): A Review. Compr Rev Food Sci F 2012; 11 (6): 546-564.

[52] Geyzen, A. Popular discourse on nutrition, health and indulgence in Flanders, 1945-1960. Appetite 2011; 56 (2): 278-283.

[53] Hutchings JA. Collapse and recovery of marine fishes. Nature 2000; 406 (6798): 882-885.

[54] Kissinger M. International trade related food miles-The case of Canada. Food Policy 2012; 37 (2): $171-178$

[55] Masley SC, Masley LV, Gualtieri CT. Effect of mercury levels and seafood intake on cognitive function in middle-aged adults. Integr Med 2012; 11: 32-40.

[56] European Food Safety Authority (EFSA). Statement on the benefits of fish/seafood consumption compared to the risks of methylmercury in fish/seafood. EFSA Journal 2015; 13 (1). doi:10.2903/j.efsa.2015.3982.

[57] Olmedo P, Pla A, Hernández AF, Barbier F, Ayouni L, Gil F. Determination of toxic elements (mercury, cadmium, lead, tin and arsenic) in fish and shellfish samples. Risk assessment for the consumers. Environ Int 2013; 59: 63-72.

[58] Olson J, Clay PM, Pinto da Silva P. Putting the seafood in sustainable food systems. Mar Pol 2014; 43: 104-111. 


\section{Acknowledgments}

Cheila Almeida wishes to thank FCT for the financial support (SFRH / BD / 60187 / 2009). The authors would like to thank António Silva at the Universidade de Coimbra for his useful comments on the manuscript.

\section{Figure captions}

Figure 1 Seafood landings between 1938 and 2010 in Portugal, with total (line) and individual production variation through the years for sardine, molluscs and cod. Source: INE [18].

Figure 2 Seafood production, imports and exports in Portugal between 1961 and 2007. Source: FAOSTAT database [17].

Figure 3 Relative house-hold consumption of the main species in Portugal assuming a per capita consumption for Portugal of $55 \mathrm{~kg}$ from FAO for 2005 (adapted from Rodgers et al. [28]).

Figure 4 Apparent seafood consumption in Portugal between 1961 and 2007 with main events and time periods. Source: FAOSTAT database [17].

Figure 5 The drivers and consequences of Portuguese seafood consumption changes (adapted from 1 Kearney [4]). 


\section{Tables}

Table 1 Average animal food consumption, in Portugal and in the world, by source, for $2010\left(\mathrm{~kg}^{-1}\right.$ capita $^{-1}$ year $\left.^{-1}\right)$. Source: FAOSTAT database [17].

\begin{tabular}{lcccc}
\hline $\begin{array}{l}\text { Average } \\
\left(\mathrm{kg}^{-1} \text { capita }^{-1} \text { year }^{-1}\right)\end{array}$ & Meat & Seafood & Milk & Eggs \\
\hline Portugal & 93.3 & 56.9 & 206.5 & 10.0 \\
Europe & 76.4 & 21.8 & 219.1 & 12.9 \\
World & 42.1 & 18.7 & 89.1 & 8.9 \\
\hline
\end{tabular}

Table 2 Trends in animal food products consumption in Portugal and the percentage of variability between periods. Source: Marques-Vidal et al. [26] and INE [27].

\begin{tabular}{|c|c|c|c|c|c|c|}
\hline & $\begin{array}{l}\text { Meat } \\
\left(\mathrm{kg}^{-1} \text { capita }^{-1} \text { year }^{-1}\right)\end{array}$ & $\begin{array}{l}\text { \% Change } \\
\text { between years }\end{array}$ & $\begin{array}{l}\text { Fish } \\
\left(\mathrm{kg}^{-1} \text { capita }^{-1} \text { year }^{-1}\right)\end{array}$ & $\begin{array}{l}\text { \% Change } \\
\text { between years }\end{array}$ & $\begin{array}{l}\text { Milk } \\
\left(\mathrm{kg}^{-1} \text { capita }^{-1} \text { year }^{-1}\right)\end{array}$ & $\begin{array}{l}\text { \% Change } \\
\text { between years }\end{array}$ \\
\hline 1987 & 71.7 & & 55.4 & & 65.7 & \\
\hline 1995 & 79.4 & 10.7 & 54.6 & -1.4 & 72.3 & 10.1 \\
\hline 1998 & 80.5 & 1.3 & 53.0 & -2.9 & 75.6 & 4.6 \\
\hline 2005 & 80.7 & 0.3 & 49.8 & -6.1 & 85.8 & 13.4 \\
\hline
\end{tabular}


Figures

Figure 1

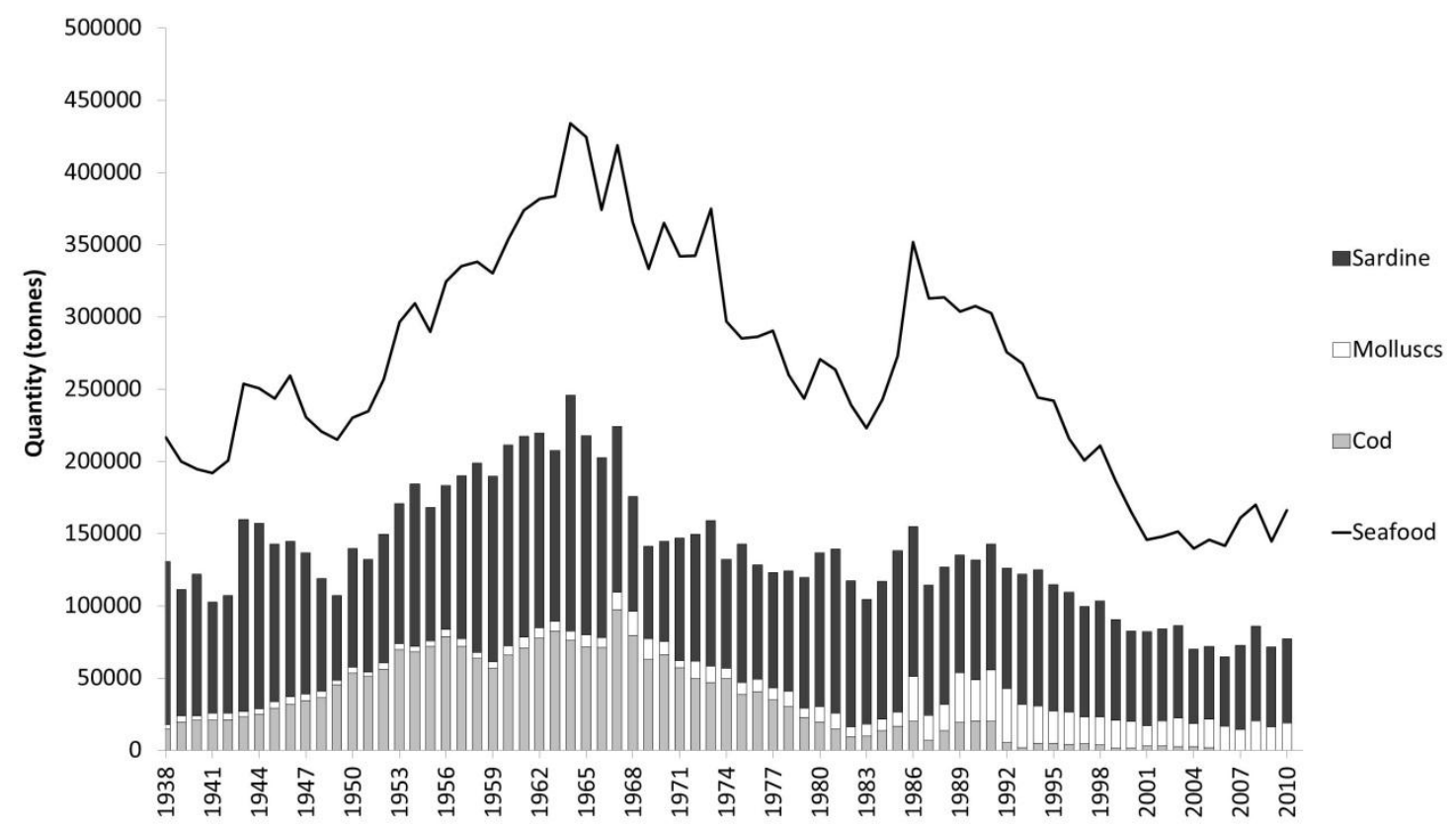

Figure 2 


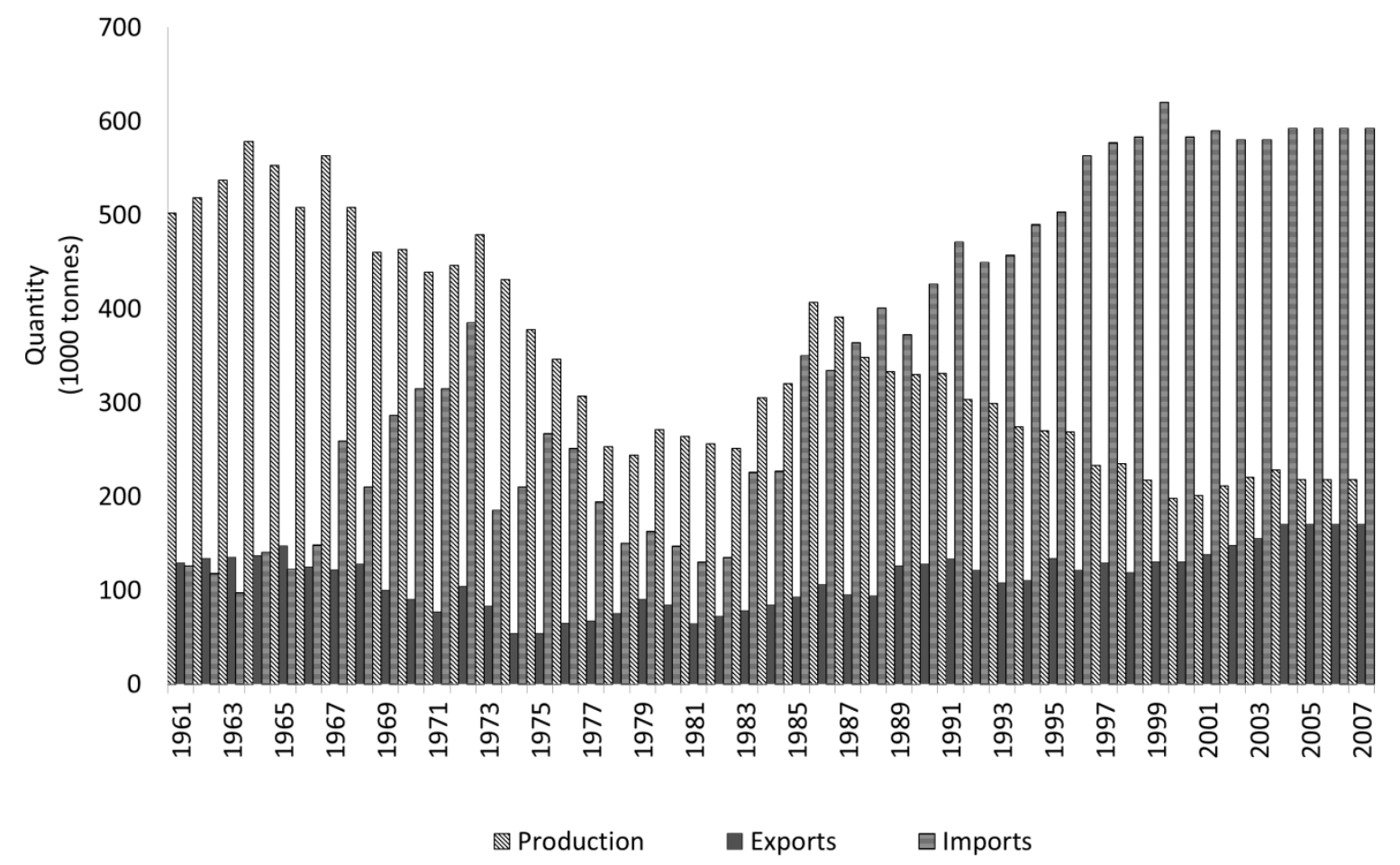

Figure 3

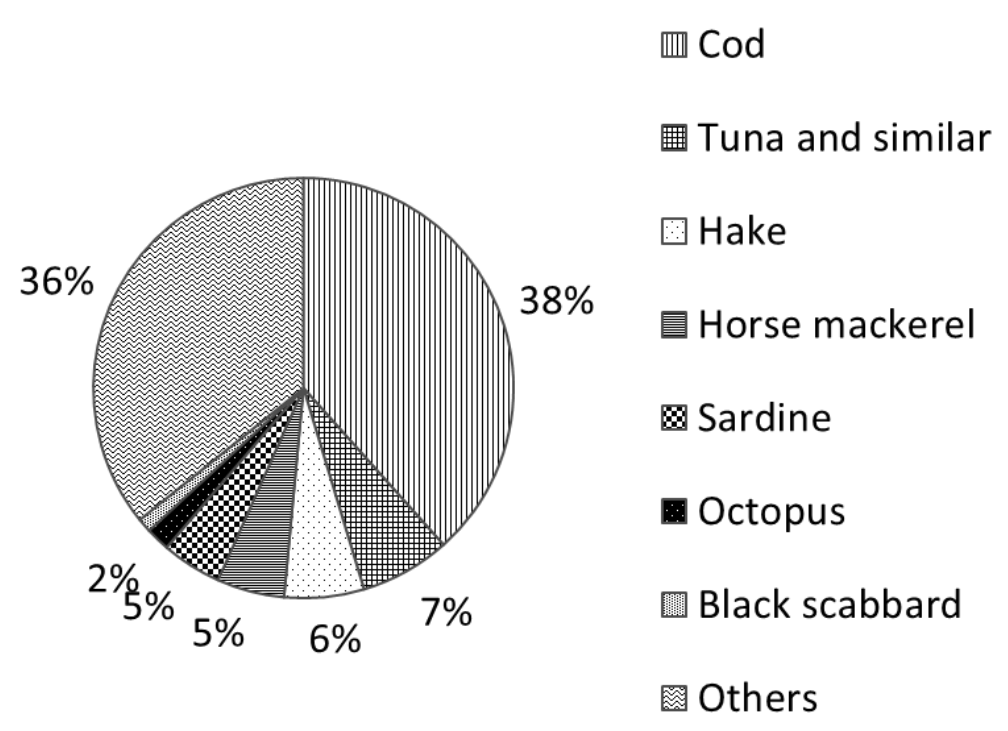

Figure 4 


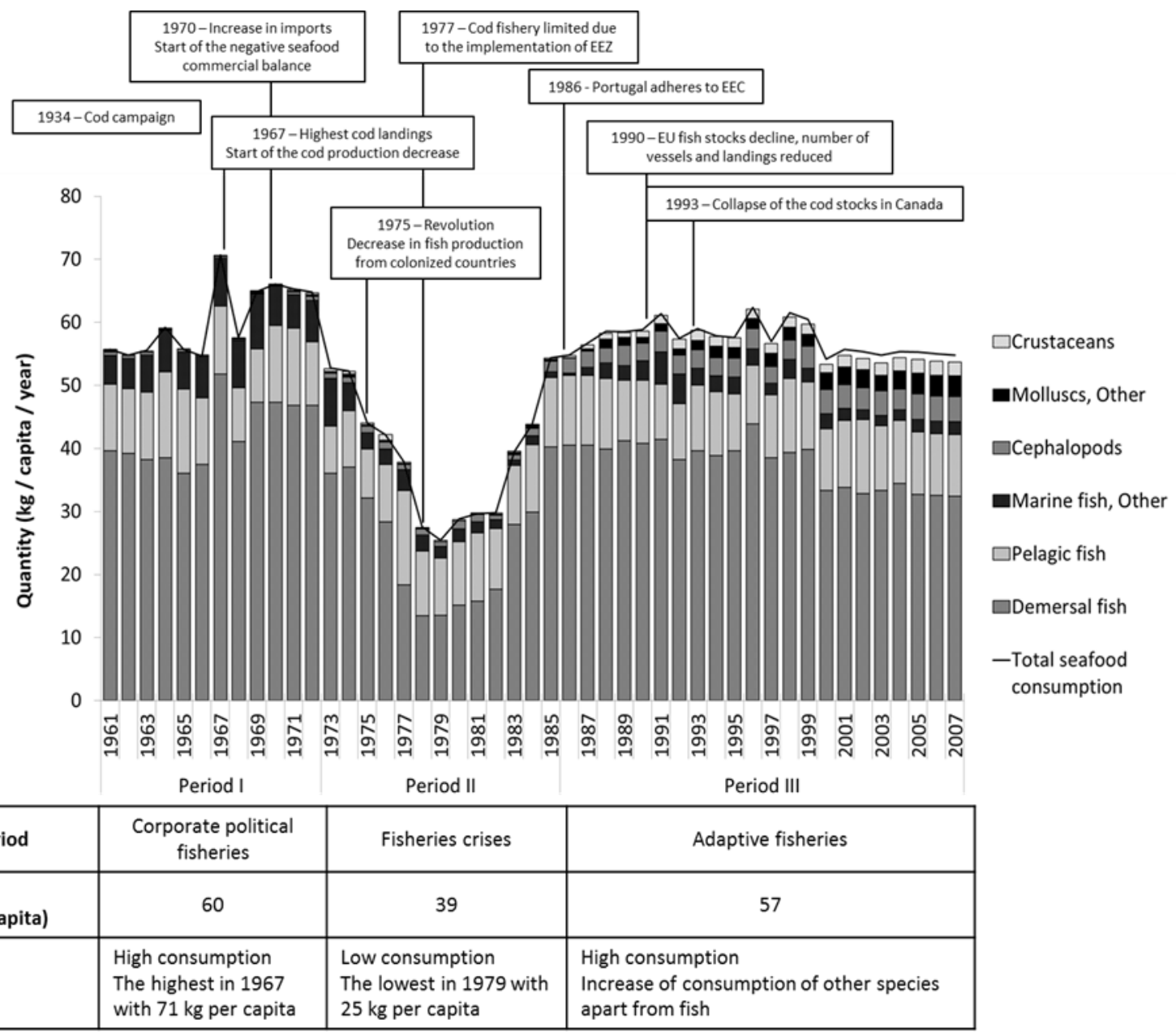

Figure 5 


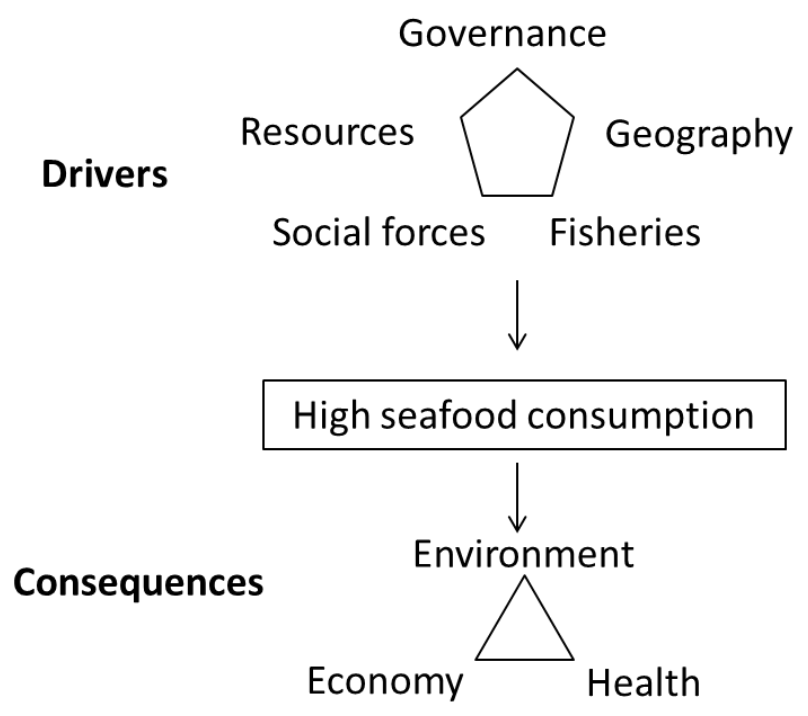

